\title{
DETERMINANTS OF FINANCIAL LEASING DEVELOPMENT IN JORDAN
}

\author{
MOHAMMAD SALAM AL-SHIAB \\ King Saud University \\ alshiab@ksu.edu.sa
}

SHAMSI BAWNIH

Princess Sumaya University

\begin{abstract}
Lease finance is being used increasingly to acquire items of industrial equipment where use is more crucial than ownership. The study presents a comprehensive overview on the state of the leasing market in Jordan in terms of legislations and market share. In addition, considerable attention is paid to the analysis of the tax \& accounting, legal, and marketing variables impact on leasing the industrial items from the industrial companies point view as a possible lessees. OLS model used for testing the study hypothesis. The study relies on collecting the data by using the questionnaire approach developed by the researcher in addition to personal interviews. Overall, 154 questionnaires were distributed on the Jordanian industrial companies listed on Amman Stock Exchange (ASE). The questionnaires returned back were 65\%. Selected statistical tests were used to check whether the data meets the model assumptions, such as normality, autocorrolation, multicollinearity tests. In addition, Cronbach Alpha test was applied to check the suitability and credibility of the questionnaire. The study results show that all explanatory variables had significant positive influence on the dependent variable (i.e. the use of lease finance). Therefore, the researchers recommend paying more attention on such variables for enhancing the use of lease finance market since such effort will influence the ultimate economic growth required.
\end{abstract}

\section{INTRODUCTION}

Leasing has been acknowledged as an important form of financing and has expanded considerably in developed and to some developing countries (Gao and Hebbert 1996; LFG 1996; Lowe et al. 1980; McAdam 1988). Prior to the 1950s in the USA, leasing was generally associated with real estate-land and buildings (Brigham and Gapenski 1985). Today, however, it is possible to lease virtually any kind of fixed asset. In 1984 about 20 percent of all new capital equipment acquired by businesses in the USA was financed through lease arrangements. Currently, leasing provides more finance worldwide than commercial papers, medium-term notes, Euro-notes, corporate bonds, or even international equities (Euromoney 2006). Anderson (1980) estimates that during the period ending in 1980 , approximately $20 \%$ on 
new acquisitions of capital goods in the US financed by leases. In the late $90 \mathrm{~s}$, leasing provides about one-eighth of the world's equipment financing requirements (Kieso and Weygandt 1998). In 2004, lease finance was the fastest growing way of financing fixed assets all over the world. It was raised by $26 \%$ counting around 580 billion dollars. The USA part counts $\$ 241$ billions taking over the funds provided through the USA banks credit, bonds and equity. In addition, in the USA it shows that fixed assets purchased by the biggest 500 companies $35 \%$ of those assets were financed by leasing in 2004 (Al Rai 2007). However, leasing is not a significant financing method used in emerging markets such as Jordan and little is known about it.

Leasing offers a way to modernize production and develop micro, small and medium-sized enterprises. Some of the common advantages of leasing seen by the lessee are: less costly financing, financing at fixed rates, protection against obsolescence, alternative minimum tax problems, flexibility, and off-balancesheet financing. The benefits for the lessor, on the other hand, are: interest revenue, $\operatorname{tax}$ incentives, and high residual value (Kieso and Weygandt 1998; Krishnan and Moyer 1994; Lasfer 2007; Lowe et al. 1980; McAdam 1988). Overall, a healthy leasing industry facilitates economic development through increased financing flows to the productive sector of the economy, which increases domestic production, improves profitability of domestic enterprises and promotes jobs creation.

Leasing takes two different forms, namely: operating leases, and financial leasing. The difference between the two types is complicated but operating leases (i.e. sometimes called service leases) is more related to contract hire since the lease period is variable and available on a short-term basis. Financial leasing (i.e. sometimes called Capital Leasing), on the other hand, is where the lessor purchases equipment and leases it to a lessee for a period approximation to the economic life of the asset and is reimbursed by the lessee for the full pay out value equipment. Mainly it is differentiated from operating leases in that they (1) do not provide maintenance service, (2) cannot be canceled unless the lessor is completely paid off, and (3) the lessee generally pays the property taxes and insurance on the leased property.

Our focus is on non-cancelable lease finance since it is the source of long-term finance regarded as an alternative of debt financing. Financial leasing is a form used extensively to finance the purchase of "big-ticket" items (Lasfer 2007). The study concerns companies in the industrial sector looking for possible leasing, which mainly deals with those bigticket items. In addition, as pointed earlier by (Lasfer 2007), financial leasing benefits are more concerned with tax advantage, cash flow, liquidity, and convenience of source of finance. There are which are the issues that the study looks at by exploring the industrial companies views through a questionnaire, as well as the exploration of the legislations and economic development that Jordan seeks in a globalized economy.

This study presents some further evidence on the terms of the leasing market in general, and lease finance in particular. The paper has two objectives. First, like earlier investigation, we hope to provide descriptive information that will add to understanding of the leasing market development in Jordan. Second, investigating how Jordanian industrial companies value and evaluate leasing as a method of financing. The main 
Since the current regulatory framework was established, numerous entities have either established leasing companies or incorporated leasing as part of their core activities. This has raised the total number of registered lessors in Jordan to 18. However, although the registered estate companies are 18 , only 6 are actively providing leasing services. According to interviews conducted by the IFC during their survey, these firms remain reluctant to enter the leasing market due to legislative ambiguities and contradictions (DOS 2007; IFC 2006).

Based on statistical figures concerning leasing market potential in Jordan, it seems that leasing activities growth rates are promising. However, a detailed examination reveals that much of the growth is due to an increase in real estate leasing constituting about $28 \%$ of total leased assets in Jordan, followed by transport equipment with $27 \%$, while production equipment represented less than 20\% (Amman Chamber of Industry 2007; Arab Bank 2006; DOS 2007).

Despite the recent developments in the Jordanian lease market, leasing remains underdeveloped as evidenced by three main indicators, namely, the share of leasing as a percent of investment in fixed assets, the growth of leasing compared to the growth of bank credit, and finally the penetration rate of leasing in the country (Arab Bank 2006; CBJ 2007). In addition, in an emerging market like Jordan face multiple challenges, foremost of which is the need to stimulate investment that increases economic growth and spurs job creation. Such transition economies featured by insufficient collateral and limited credit histories for micro, small, and medium-sized enterprises and consequently shortage of credit available at prices and maturities to meet their financing needs (Jordan Investment Board 2007; Ministry of Industry and Trade 2007; Ministry of Planning 2007).

It could be argued that an active leasing sector provides an alternative to bank finance, broadening choices for micro, small, and medium-sized companies, and promoting competition in financial services. Greater competition and financing options stimulate domestic production, economies growth, and job creation. It is evident that leasing as a means to finance productive assets remains under-utilized in Jordan since only $7 \%$ of the total leasing volume used to finance fixed assets compared to $15 \%, 18 \%$, and $30 \%$ in Pakistan, Italy, and USA, respectively (Euromoney 2006). With leasing usid to a significant extent to finance real estate for personal use as it is the case in Jordan, the potential benefits that an active leasing sector can provide to micro, small, and medium-sized enterprises by financing equipment purchases have yet to be realized fully, and thus have not contributed significantly to the growth of the Jordanian economy (IFC 2006).

The growth of leasing in Jordan can not be fully attributed to the development of the sector per se as the volume of leasing finance increased proportionately with other types of financing such as bank loans which increased by more that JD 2 billions in 2005 compared to only JD160 million in the lease industry (CBJ 2005). Therefore, despite the large increase in leasing volumes during the 2004 and 2005 , leasing represented only by $1.7 \%$ of total banking credit, further evidence that leasing can play a much larger role in the Jordanian economy. 
Jordan's volume of leasing as measured against gross domestic product with some comparisons is presented in Table (2). It is evident that the leasing sector in Jordan has significant room to grow given its penetration rate is only 0.01 compared to average of 0.5 for countries with transitional economies

Table-2: A Comparison of the Penetration Rates*

\begin{tabular}{|l|c|}
\hline \multicolumn{1}{|c|}{ Country } & $\begin{array}{c}\text { Penetration } \\
\text { Rate (\%) }\end{array}$ \\
\hline $\begin{array}{l}\text { Countries with developed } \\
\text { economies }\end{array}$ & \\
\hline Austria & 2.73 \\
\hline Germany & 2.29 \\
\hline Canada & 2.11 \\
\hline USA & 1.91 \\
\hline France & 1.56 \\
\hline $\begin{array}{l}\text { Countries with transitional } \\
\text { economies }\end{array}$ & \\
\hline Russia & 0.87 \\
\hline Egypt & 0.76 \\
\hline Malaysia & 0.36 \\
\hline Jordan & 0.01 \\
\hline
\end{tabular}

*Leasing Volume as \% of Gross Domestic Product. Source: Intemational Finance Corporation Survey, Amman, P. 23, 2006.

and 2.12 for developed economies (IFC 2006).

Reflecting the overall rise of the leasing industry, leasing by Jordanian banks, both conventional and Islamic, increased substantially in 2005. Leases written by commercial banks grew from JD 7 millions in 2004 to JD 21 millions in 2005. Islamic banks financed ID 27 millions worth of leases in 2005, which is a significant increase, compared to ID 3.5 millions in 2004. It is interesting to note that all of the Islamic banks' leasing transitions in 2005 were to finance real estate whereas such transactions represented only $38 \%$ of leases issued by commercial banks, an issue needs to be highlighted. The remaining $62 \%$ of commercial banks leases were issued to finance purchases of production equipments, vehicles, and other assets (Arab Bank 2006; DOS 2007; Jordanian Islamic Bank 2007). If leasing industry required contributing in increases economic growth and spurs job creation, the percentage of financing the purchases of production equipments through leasing contracts should be much higher than what is existed in both, commercial banks and Islamic banks. It should be noted that 12 out of 15 Jordanian banks that were surveyed did not express interest in offering leasing despite the fact that legislation allows it. Some banks explained that leasing is not part of their credit policy while others pointed to legal constraints and lack of capacity (IFC 2006).

Regulatory Environment and Costs Associated with Leasing Transactions

One of the key factors, which promote the development of leasing in any country, is a transparent and effective legal framework, which clearly regulate the relationships between the parties to a lease (Gao and Hebbert 1996; McAdam 1988; Ross and Stephen 2001). It is crucial that legislation provides for a clear definition of what constitutes a leasing transaction, offers a fair balance of rights and responsibilities among the parties to a lease and establishes efficient mechanisms for repossessing lease assets.

In Jordan, there is no supervision of the leasing activities, nor is any body empowered to regulate lessors. However, legislation does impose licensing and 
minimum capital requirements on lessors, which restricts competition and limit the entry on new players. The rationality of such argument, however, comes from the fact that establishing minimum capital requirements are necessary for deposit-taking institutions primarily as a means to protect depositors. But, since leasing companies do not accept deposits, the imposition of high minimum capital requirements reduces new entrants, thus restricts competition and innovation. International best practice demonstrates that licensing and minimum capital requirements may hamper the development of leasing markets (Gao and Hebbert 1996; IFC 2006; Kraljic 1990). Lowe et al. (1980) argue that growing number of lessees has helped the increase in leasing market knowledge in the USA and European countries, whilst the entry of new lessors has further increased the elasticity of demand facing the individual lessor. Consequently, price cost margins have been reduced, a result would be predicted by traditional price theory.

In accordance with the law on leasing and related regulations, leasing contracts as well as information regarding movable leased assets are required to be registered by the Ministry of Industry and Trade. International best practice demonstrates the usefulness of legislation that requires registration of titles to movable assets. Creation of movable asset registry, which would cover leased assets as well, is undoubtedly an important step to ensure the protection and enforcement of property rights. In this respect, Jordan is ahead of many other countries in the region, which do not have registries for movable assets (Ministry of Industry and Trade 2007).

An interview conducted by the researchers with the Ministry of Industry and Trade authority conclude that the law on leasing requires registration of title to leased assets with the Ministry who manages the Leased Asset Registry. However, in addition to registering titles, leasing contracts themselves are also subject to registration according to implementing regulations. This additional administrative burden does not, in essence, provide any benefits to the parties to a lease, nor does it serve any economic or regulatory purpose. Further, legislation requires that certain transactions involving special types of assets, such as real estate or vehicles, be recorded in specialized governmental agencies. Thus, a contract to lease, for example, a vehicle would have to be registered in the traffic police department. However, the mandatory registration of leasing contracts solely by virtue of the fact those parties have entered into a leasing agreement id an administrative burden, increasing transactions costs and acting as a disincentive to leasing.

It is important that legislation recognizes various types of leasing such as sale and leaseback, and sub-leasing. Sales and leaseback arrangements are essentially a means to finance working capital whereby an entity or person who already owns an asset, sells it to a lessor and simultaneously leases the asset back. This frees up cash that can be used as working capital while retaining use of the requirement. Sub-leasing is an important arrangement to reduce the risk of a lessor in cases when a lessee cannot meet its obligations under a contract. Sub-leasing arrangements are also effective in cross border leasing where a lessor located in one country leases an asset in a different country to its subsidiary or agent. Therefore, sales and leaseback transactions and sub-leasing require specialized legal treatment to avoid 
are more expensive and less competitive compared with those of banks. Further, the General Sales Tax Law does not define exactly how the exemption will be applicable to leasing transactions even for banks. Therefore, due to ambiguous regarding the treatment of sales tax for leasing transactions, sales tax is not consistently calculated by lessors, lessees, or tax authorities._In addition, sales tax regulation is not clear on the mechanism for setting-off sales tax for leasing transactions. Such ambiguity has significant implications including higher costs to lessees and potential legal liabilities for all parties concerned. In fact, the survey run by the IFC indicated that uncertainty related to sales tax was a major reason that some potential lessors, who have already been licensed, have yet to venture actively into the market.

Other costs associated with leasing transaction in Jordan is that leased vehicles must be registered not only with the Traffic Department as for other vehicles, but also must be registered in the Ministry of Industry and Trade which is responsible for registering all movable leased assets charging a registration fee. Such fee adds to the cost of leasing assets and adds to bureaucratic delays as well. The second problem arises during registration of real estate in the Land Department. Based on a resolution issued by the Bureau of International of Laws, leasing contracts for real estate are considered simply rental contracts for which a series of fees are charged against the rentals value in the aggregate, these fees represent approximately $2.75 \%$ of the value of the real estate (IFC 2006). This additional fee significantly increase the cost of leasing compared to loans financed by banks and non-bank mortgage lenders.
The above-mentioned impediments increase the cost of leasing transactions and result in unnecessary delays for the parties to a lease. Improvements to registration procedures along with the establishment of consistent and simple processes will help to eliminate costly duplication and unnecessary steps in the registration process for leased assets.

\section{LITERATURE REVIEW}

Empirical studies of leasing have reported high ex ante returns for lessors, and by implication, high lease rates paid by lessees (Schallheim et al. 1987). Lease et al. (1990) documented high-realized returns on lease finance contracts, although the realized returns were less than the expected returns. Further, they found that realized salvage values tended to exceed greatly the actual salvage values on which the lease contract was based. The focus was more on the leasing of plant and machinery, which on average constitute the largest proportion of fixed assets. Motives for leasing assets identified are taxation, debt capacity, and agency costs as the main motives. In this section, these motives are summarized.

\section{1- Taxes and Leasing}

Traditionally, the theory of financial leasing has focused on the differential tax position of the lessee and the lessor as the primary rational for leasing (Barclay and Smith 1995; Brick et al. 1987). The fundamental argument is that, if a firm is not in a full taxpaying position purchasing and depreciating an asset may be costly because it can use only a low capital or depreciation tax allowance. However, by leasing the asset, the lessor would claim the tax allowances, and the tax benefits could be transferred indirectly to the lessee through lower lease payments. 
Thus, while the after-tax NPV of the project if the asset is purchased could be negative, the leasing could reverse this position.

The empirical evidence provided to date on the influence of taxes on leasing is mixed. For example, (Lewis and Schallheim 1992) model the leasing and borrowing decision. They focus on leasing as a means of selling excess, non-debt tax deductions. In their model, non-debt tax shields are sold via leasing, therefore reducing the potential redundancy with interest deduction, making the marginal value of debt positive. The lessee responds by using additional debt. Under this model, the benefits from leasing are realized even if the marginal tax rate is the same for the lessee and the lessor. Barclay and Smith (1995) find strong evidence of tax effects. Using US companies data, they find that companies with high proportion of tax-loss carry forward rely more on lease finance. Lasfer and Levis (1998) show that leasing is driven by taxes for large companies only. They add, unlike small companies, the tax rates of large lessee companies are substantially lower than the non-lessee large companies. In contrast, small companies appear to have the same tax position irrespective of their leasing level. (Ross and Stephen 2001) offer a comprehensive analysis of the leasing industry in China, which is becoming a viable avenue for foreign investors after encountering serious difficulties in the late 1980 s and early 1990 s. They conclude that lower business tax rate is available under Financial Leasing - provided that the contract makes the critical distinction between a sale of goods and a lease. They argue that more generous tax incentives concerning depreciation would hasten the development of the leasing industry.
In contrast, studying the capital leases, (Finucane 1988) shows that tax-related factors are not significantly associated with the level of leasing. Such result could be justified by arguing that Finucane looked only at "capital" leases, as defined by FASB Statement 13 , and therefore, tax factors would not be expected to be important because the Internal Revenue Services (IRS) treats most capital leases as installment sales contracts for tax purposes. Opposite Finucane results, (Vora and Ezzell 1991) find significant tax rate differences between lessees and lessors, although they found that the lessee's tax rate is not necessarily lower than the respective lessor's. Merhan et al. (1999) supports, however, Finucane findings since the study does not find a strong correlation between taxes as proxies by the ratio of reported tax less change in deferred tax over earnings before interest and tax and leasing. Sharpe and Nguyen (1995) construct two alternative proxies for a firm's tax status: the ratio of tax expense over pre-tax income and a dummy variable equal to one for firms that reported in their financial statements tax-loss carry forward to proxy for the inability of the firm to take full advantage of the tax benefits of ownership. These two measures are found to be significant, suggesting that capitalized leases are used more heavily in firms for which the tax-benefits of ownership appear low. (Eades and Marston 2002) provide little support for the taxes and financial contracting effects on the decision to lease. Consistent with (Smith and Wakeman 1985), they report that the type of asset leased and the type of contract provisions stipulated in the lease contract contribute to the leasing decision.

These mixed results are partly driven by the difficulties of testing empirically the

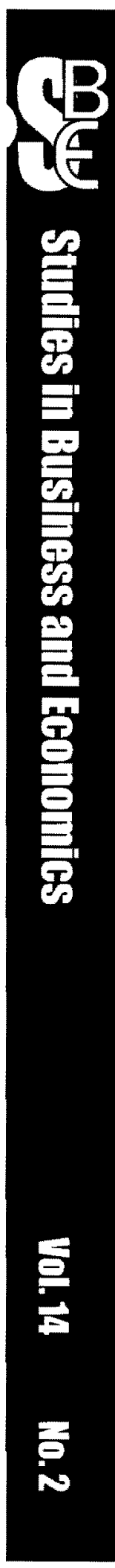

33

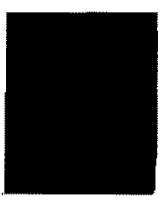


determinants of leasing. (Graham 2003), argues that any relationship between leasing and taxes is likely to be spurious because leasing endogenously reduces the effective tax rate of the lessee as leasing expense is tax deductible and the definition of leases in the financial statements is not the same as that of the tax authority. These particular problems make the testing of the impact of taxes on leasing complicated.

Brick et al. (1987) extended the tax-based analysis to consider economies of scale in structuring lease contracts and the cost of managing cash flows in the presence of default risk and interest rate uncertainty. However, (Krahan and Meran 1987) and (Lease et al. 1990) consider the role of information asymmetries between the lessee and the lessor regarding the residual value of the leased asset as a further explanation for lease financing.

\section{2- Corporate Debt Capacity and Leasing}

The overall empirical evidence concerning debt variable and its relation with leasing is mixed. For example, many studies have considered leasing as a substitute for corporate borrowing (Adedeji and Stapleton 1996; Finucane 1988; Lasfer and Levis 1998; Marston and Harris 1988; Mukherjee 1991). Smith and Wakeman (1985) offer a comprehensive analysis of the rationale for leasing that helps to explain many of these seemingly anomalous empirical findings. They argue that the Ang and Peterson findings can be explained across firms by examining the characteristics of firms' investment opportunity sets. Finucane (1988) supported Ang and Peterson findings by arguing that relationship between debt and lease financing exists, and shows that firms in certain industries, including air transport and retailing, rely more heavily on lease financing than others. Marston and Harris (1988) studied changes in the debt ratio and lease ratio (i.e. capitalized leases to total assets) for individual firms over time and found them to be inversely relatedconfirming that debt and lease financing are substitutes. Mukherjee (1991) finds through a questionnaire distributed to 103 chief financial officers of large firms whether they view debt and leasing as substitute, complements, or independent financing instruments. While 22 of the respondents felt that the relationship is complementary and 31 saw the two as independent, 47 reported that lease and debt financing are substitutes. Adedeji and Stapleton (1996) report that the degree of leasing and debt financing are negatively related, as predicted by the theory.

However, other empirical evidence finds that leasing is a complement, not a substitute, to debt financing (Bathala and Mukherjee 1995; Krishnan and Moyer 1994). Focusing on capital leases, (Krishnan and Moyer 1994) hypothesize that compared to ordinary debt; leasing reduces bankruptcy costs while having all the advantages of secured debt. Under these consideration leases should be more widely used by riskier, less-established firms. They find that lessee firms have lower retained earnings, high-growth rates, lower coverage ratios, higher debt in their capital structure, higher operating risk and lower $z$ score (a measure of bankruptcy risks) than non-lessee firms.

Sharpe and Nguyen (1995) analyze the intensity to use both operating and Financial Leasing in the US. They find that leasing propensity, defined as the ratio of operating and capital lease over book value of fixed 
assets, is substantially higher for lowerrated, no dividend-paying and poor-cash firms. Their results suggest that in the US, leasing used extensively by firms that are likely to face relatively high premium for external funds. Lasfer and Levis (1998) who they show that companies that are likely to face higher premiums on external funding use leasing depending on the size of the firm. They report that large companies that lease have large gearing and relative proportion of bank loan and overdraft in their debt. These companies appear to lease to reduce their interest costs. In contrast, for small companies, leasing is a substitute for debt financing contradicting the results reported by (Mukherjee 1991) previously showing that leasing is a substitute for debt financing for large sized companies, and not for small ones.

\section{3-Agency Costs and Leasing}

There has been an increasing tendency to view leasing in the broader context of financial contracting (Barclay and Smith 1995; Sharpe and Nguyen 1995; Smith and Wakeman 1985). While not denying the potential importance of taxes and the substitutability between leasing and debt, newer literature has placed greater emphasis on the relative abilities of different types of financial contracts to control agency costs. Financial contracting theory suggests that company characteristics such as business risk and the nature of the investment opportunity should affect contracting costs and thus the choice to lease rather than buy assets. Conflicts raised by the agency costs theory are referred to as the asset substitution problem which arises from the possibility that the borrowed funds may be used to finance other more risky projects or to be distributed as dividends to shareholders and can lead to the under investment problem that may result from the fact that lenders are likely to refrain from financing some positive NPV projects that are difficult to monitor because contacts or covenants cannot cover all contingencies (Myers 1977). Leasing mitigate these conflicts because the asset is purchased by the lessor.

Empirical studies have provided some support for these predictions (Barclay and Smith 1995; Graham et al. 1998; Sharpe and Nguyen 1995). The theoretical literature has also suggested that a corporation's ownership structure, which in turn affects managerial and investor incentives, should influence the decision to lease assets (Smith and Wakeman 1985). Merhan et al. (1999) argued that a manager with a large ownership stake, measured by the fraction of common shares owned by the company's chief executive officer (CEO), might prefer leasing to reduce personal exposure to obsolescence or other assets specific risks. The researchers also include in their study other variables that reflect business risk, investment opportunities, tax considerations, and_debt. Merhan et al. variables selected based on the financial contracting literature claiming such variables have the influence on determining the contractual form to finance a new asset. Their findings is that CEO ownership is positively related to companies' leasing activity regardless of whether they include only capitalized leases or both capitalized and operating lease as a dependent variable. Their results however, provide mixed evidence on the relationship between debt and leasing. Tobit estimates suggest a complementary relationship between debt and capitalized lease, while they do not find evidence of a significant interaction between debt and operating leases.

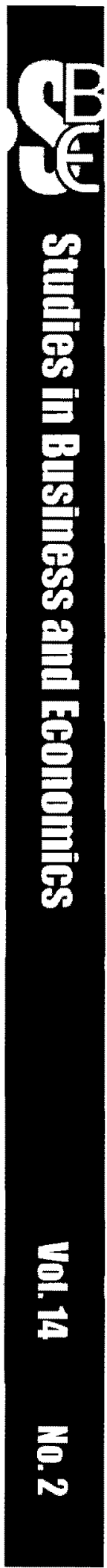

35 
Stulz and Johnson (1985) developed a model which predicts that under the agency framework some profitable projects will not be undertaken by a firm which can use only equity or unsecured debt to finance them but will be undertaken if they can be financed with secured debt or leasing. Smith and Wakeman (1985) identified other cases where leasing reduces occur if the value of the asset is not specialized to the firm and/or if the lessor has market power and a comparative advantage in asset disposal. Similar conclusions reached by (Williamson 1988) who concluded that assets that are easily redeployable (i.e. assets with resale value and not firm-specific) are likely to be leased. Empirically, (Finucane 1988) and (Krishnan and Moyer 1994) find that leasing activity in the US is more prevalent in certain industries, such as transportation, services and wholesale and retail trade because the assets leased in these industries, such as aircraft and retail space, are easily redeployed. Moreover, (Finucane 1988) shows that firms with mortgage secured notes or bonds are more likely to use leasing. This suggests that firms with assets that make good collateral are also likely to have assets conductive to leasing. Moreover, (Barclay and Smith 1995; Myers 1977; Stulz and Johnson 1985) find that US firms with greater growth opportunities, as measured by book-to-market ratio, rely more heavily on lease financing because under the agency cost framework, these firms are likely to suffer from sever agency conflicts, and thus cannot use debt financing. They also find that regulated firms in the US, such as gas and electric utilities and telecommunications, use lower proportion of capitalized leases but higher proportions of long-term debt and ordinary debt because regulation reduces the possibility for corporate under investment as the regulator oversees these firms' investments decisions. Smith and Wakeman (1985) predict that leasing is more likely to occur if the firm is closely held because leasing acts as a risk reduction mechanism for such firms, especially if the lessor has a comparative advantage in disposing of the asset in the second hand market.

Empirically, (Mukherjee 1991) shows that, the desire to lay off obsolescence risk is one of the motives for leasing. Merhan et al. (1999) finds that firms with higher proportions of insider ownership engage more in leasing. Finally, other studies considered firm size as a proxy for the agency costs and argue that large diversified firms are less likely to lease assets because they are less concerned with external redeployment possibilities. Consistent with these arguments, (Barclay and Smith 1995; Lasfer and Levis 1998; Sharpe and Nguyen 1995) find that small firms are more likely to lease their assets to finance growth opportunities and to overcome debt constrains.

The analysis above suggests that there are costs and benefits of leasing, which are likely to be more pronounced for the industrial items given its importance in the firm's balance sheet. Given these costs and benefits, it is an empirical question as to whether leasing in the long run in an emerging market like Jordan create or destroy value. The following section explains the methodology employed to answer such concern.]

\section{DATA AND METHODOLOGY}

Our aim is to specify a model for the empirical testing that incorporates the 
potential impact of selected variables based on the previous literature on leasing. As mentioned in the theoretical and empirical studies, many variables could be investigated to see whether they have a relationship with leasing. The common issues in these variables are that they are obtained mainly from companies" annual reports. Studies samples, moreover, clarified through leasing associations or through databases readily to use. Variables considered in the previous studies, and could be in our study, are: firm size, retained earnings, turnover growth, coverage ratios, leverage, operating risk, business risk, z-score a measure of bankruptcy risks, ownership structure, firm's tax position, company's credit rating, dividend-paying, market-to-sales, market value of common equity over book value of common equity, and cash ratios. In Jordan, however, nor associations concerning leasing market exists, neither a database is available. Therefore, the researchers forced to rely on a questionnaire they developed for measuring Jordanian industrial companies views on the possible relationships and influences of selected variables on leasing market in Jordan. Other issues limited our study: First, leasing industry possible influence on companies expected to be on the long run not on the short-run. (Beattie et al. 2000) reported that an average life of the leased asset is 16 years. However, regulated leasing market in Jordan has started to see the light recently starting from 1999. Adopting the previous empirical studies approaches is not possible because of the time limit. Second, previous empirical studies studied leasing market mainly in developed countries like the US and European countries where investigating the companies characteristics lease assets is possible. Other studies investigate the leasing market in developing countries limit their research on data descriptive and legal developments (Gao 1995; Gao and Hebbert 1996; Ross and Stephen 2001). It can be argued that in the absence of well-established leasing market in terms of history, regulations, and knowledge, variables considered in the previous empirical studies cannot be employed. The study, therefore, limit its empirical objective by investigating how Jordanian industrial companies value and evaluate leasing as a method of financing by looking at tax and accounting, legal, and marketing variables.

The choice of the variables in this study are based on previous empirical studies in the emerging leasing market along with the theoretical arguments presented in brief earlier. For example, (Ross and Stephen 2001) argue that for China's leasing industry to develop, it needs a sound legislative foundation establishing the basic elements of the transaction, the rights and obligations of the parties, and the basis for enforcement. However, the proponents of a vigorous leasing industry have argued that China could further stimulate expansion by providing greater tax incentives. The same argument reported by (McAdam 1988) saying that as leasing is based on accounting, tax and legal infrastructures, a great deal of variation naturally exists in lease products acceptable among countries. He added, this variation has not inhibited severely the growth of international leasing because leasing adapts to almost any legal and regulatory regime. Further, a study conducted by (Gao 1995) concludes that leasing business in Poland is underdeveloped and ten major problems highlighted in the study. The lack of leasing regulations, unpredictable tax law, very few long-term financial lease availability, poor

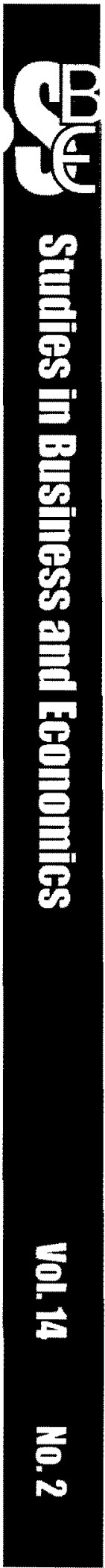

37 
lease market information availability, unclear legal position on leased items ownership are on the top of the list. In conclusion, the leasing market in Poland is extremely underdeveloped in terms of both number and size of deals. Further, (Gao and Hebbert 1996) conclude that the 1990s witnessed the increasingly developing leasing market in Eastern European countries: witnessing the establishment of leasing associations, the growth of cross-boarder and domestic leasing, and the evolution of new accounting regulations in the region. However, Simon add that apart from the range of systematic market imperfections, other common problems slackening the pace of the lease industry including the dearth of medium and long-term financing, especially the shortage of creditable banking and financial institutions to facilitate secondary equipment market, and the absence of appropriate protective legislations. That is legislations are hastily enacted and are often incomplete, ambiguous and open to manipulation. In access to international leasing markets and the cautious approach of foreign investors is a corollary effect of the absence of a legal system for corporate control and ownership protection. Simon ends his conclusion by highlighting the fact that the region also suffers from high risks of long-term investments and unpredictably changing tax laws.

Our empirical objective in this study is to investigate how Jordanian industrial companies value and evaluate leasing as a method of financing. Therefore, the study explores some of the variables mentioned above, namely: tax \& accounting, legal, and marketing as independent variables might influence the leasing emerging market in Jordan hypothesizing that such variables have significant positive impact. A questionnaire has been designed counting 20 questions covering the four variables, namely; the use of Financial Leasing as a dependent variable, tax \& accounting, legal, and marketing as independent variables. The structure of the questionnaire is as follows: questions from one to four related to the dependent variable, questions from five to thirteen related to tax and accounting variable, questions from fourteen to sixteen related to legal variable, and finally questions from seventeen to twenty related to marketing variable.

The industrial companies listed on ASE in 2008 are 90 companies (ASE 2008). It is decided that industrial companies selected to fill the questionnaire should have total assets not less than $\$ 5$ millions as it is the average total assets of the industrial companies in Jordan reported over the year 2008 (ASE 2008). Krishnan and Moyer (1994), for example, study the UK companies and set three requirements for their sample; company's assets should be greater than $\$ 200$ millions, no holding companies in order to avoid duplication with subsidiaries, and no regulated utility and financial firms. However, following Krishnan et al. company's size limit is not possible because of the size difference between Jordanian industrial companies and the UK companies. The logic behind such requirement comes from the fact that assets industrial items are costly, which force companies to look for many different financing options, leasing is one of them. Therefore, having total assets not less than $\$ 5$ millions excludes those companies who can manage having the items by paying cash without influencing significantly the companies' liquidity indicators or even 
through bank loans without influencing significantly the companies' coverage and debt ratios. It could be argued that such companies do not have in general that high costly-fixed asset. Based on the mentioned requirement, industrial companies left to explore its views on leasing are 77 companies representing $86 \%$ of the industrial companies listed on ASE.

Industrial companies met the requirement are selected for filling the questionnaire by the senior financial department employees in each company. One hundred fifty four questionnaires were distributed, and the returned representing almost $65 \%$. To examine the effect of tax \& accounting, legal, and marketing on the use of Financial Leasing, therefore, the following null hypothesis is proposed:

"H01: There is no influence by regulatory and tax, legal, and marketing variables on the use of Financial Leasing".

In order to make our hypotheses more concrete, we specify and estimate an empirical model linking tax \& accounting, legal, marketing, and the use of Financial Leasing. The models to be estimated are based on the following equations:

$$
L E A S=\alpha_{i}+\beta_{1} T A C+\beta_{2} L E G+\beta_{3} M A R+\varepsilon
$$

Where: for firm $i$ at time $t, \alpha$ is the constant term, $\beta$ is a vector of regression slope, LEAS, TAC, LEG, and MAR are vectors of Financial Leasing, tax \& accounting, legal, marketing, respectively. Moreover, $e_{i j}$ is the disturbance terms. The disturbance term represents two sets of factors. First, it represents the effect on the dependent variable (firm performance) of all variables other than the ones included in the study. Second, even if the variable included was the only identifiable variable influencing the dependent variable, it should not be expected that the same level of dependent variable would stay year after year. The disturbance term, therefore, is included to allow for the basic random unpredictability of human behavior (Thomas 1997).

The multivariate analysis carried out in this study is not only multiple regression routines but also stepwise regression technique in order to determine which explanatory variables are "best" in explaining firm performance variation over the period under consideration. One of the problems of undertaking any multiple analyses, however, is that there may be multicollinearity between independent variables. The multiple regression models assume that there is no linear relationship between the values of the independent variables. If the linear relationships exist then it becomes impossible to compute the estimators (Bi). It is stated that the variances and hence standard errors of the estimators (coefficients of the explanatory variables) will tend to be large (inflate standard errors) whenever there is a high degree of multicollinearity (Thomas 1997). Since there is no reason why multicollinearity should affect our estimators of these standard errors, their size will be reflected in any estimated standard errors that we compute. This is the major possible adverse factor when multicollinearity is present - large standard errors and hence large estimated standard errors. That is, our estimates will lack precision and we will be very uncertain about true parameter values. Therefore, multicollinearity checked not only by testing for Pearson Correlation Coefficients

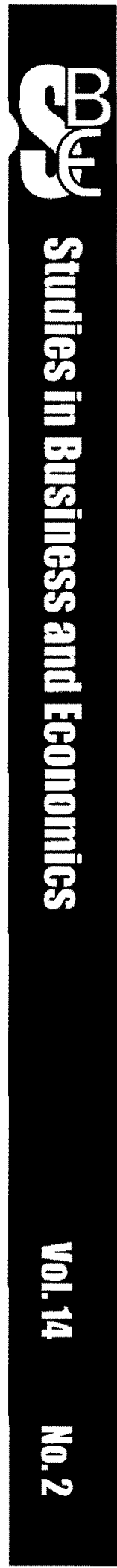

39 
as it has been adopted by previous empirical studies (Street and Bryant 2000; Wallace and Naser 1995; Wallace et al. 1994) ${ }^{4}$, but also by running the stepwise regression technique (Malone et al. 1993). Malone et al. (1993) reported that an examination of the regression coefficients was made at each step of the stepwise procedures. This examination showed that as variables were removed from the model, the coefficients of these variables, their standard errors, and the mean-square error remained relatively stable. In the presence of multicollinearity, as variables were removed, one would expect these values to exhibit instability.

An important point to note is that, in order to undertake ordinary least-squares (OLS) multiple linear regression, the data must fulfil certain conditions, i.e. normality, homogeneity (equal variance), uncorrelated ${ }^{5}$ and linearity. The most commonly suggested approach to check whether or not the data fulfil these conditions is an analysis of the residuals (Kinnear and Gray 1995; Norusis 1995). In this study a Q-Q plot of residuals was analysed and formal tests of normality of residuals (skewness, kurtosis and K-S Lilliefors) were undertaken to check the normality assumption (Norusis 1995). Furthermore, the linearity and homogeneity assumptions were checked by analysing the scatterplots of the regression standardised predicted values against the residuals_(Kinnear and Gray 1995). Finally, a commonly used statistic for testing the existence of autocorrelation among residuals is the Durban-Watson (DW) statistic, which will be, employed (Maddala 2001). However, since the study using the questionnaire approach in testing the hypothesis, Cronbach Alpha was adopted for testing whether the questions included measuring the variables considered. As Cronbach Alpha was $74.79 \%$, such a result highlighting the fact that the questions built up were strong enough to measure the variables considered (See Appindix 1/C).

\section{EMIRICAL RESULTS}

Multivariate regression analysis is employed to determine the impact of tax \& accounting, legal, and marketing on financial leasing. The descriptive analysis shows that $90 \%$ of the sample were males, while the rest were females. In addition, most of the candidates age between 26 to 30 and 36 years or above representing $40 \%$ and $33 \%$ of the sample, respectively. Table (3) provides the results in more details.

As it can be seen from Table (3) that most of

4 When we test for the multicollinearity, we look at the correlation coefficients, which should not be considered
harmful until they exceed 0.80 as it is argued by Judge, G., W. Griffiths, R. Hill, H. Lutkepohl, and T. Lee (1985),
The Theory and Practice of Econometrics ( 2 nd ed.). U.S.A - New York: John Wley \& Sons. while Street, D. L. and
S. M. Bryant (2000), "Disclosure Level and Compliance with IASs: A Comparison of Companies with and without
U.S. Listing and Filings'," The International Joumal of Accounting, Vol. 35 (No. 3). argued that it should not exceed
0.90 . Wallace et al. (1994), however, considered coefficient of correlation exceeding 0.77 high enough to cause
multicollinearity concern.

5 Correlation between the error terms arising in time-series data which called autocorrelation of serial correlation. If autocorrelation exists, that means the error term $u t$ at time period $t$ is correlated with error terms $u t+1, u t+2, \ldots$ and $u t-1, u t-2, \ldots$ and so on. Such correlation in the error terms often arises from the correlation of the omitted variables that the error term captures. The correlation between $u t$ and $u t-k$ is called an autcorrelation of order $k$. the correlation between $u t$ and $u-2$ is called the second-order autocorrelation and is denoted by $p 2$, and so on. Hence. there are (n-1) such autocorrelations if we have $n$ observations. The consequences of autocorrelation errors are: 1) the leas squares estimators using the multiple regressions are unbiased but are not efficient, and 2) the sampling variances are biased and sometimes likely to be seriously understated. Thus, $R^{2}$ as well as $t$ and $f$ statistics tend to be exaggerated (Maddala, 2001). 
Table-3: Study Sample Descriptive Analysis

\begin{tabular}{|c|c|c|}
\hline Variable & & $\begin{array}{c}\text { Percentage } \\
(\%)\end{array}$ \\
\hline \multirow{2}{*}{ Sex } & Male & 90 \\
\hline & Female & 10 \\
\hline \multirow[t]{4}{*}{ Age } & $\begin{array}{l}25 \text { years or } \\
\text { below }\end{array}$ & 6.7 \\
\hline & $26-30$ years & 40 \\
\hline & $31-35$ years & 20 \\
\hline & $\begin{array}{c}36 \text { years or } \\
\text { above }\end{array}$ & 33.3 \\
\hline \multirow[t]{4}{*}{$\begin{array}{c}\text { Education } \\
\text { Level }\end{array}$} & $\begin{array}{l}\text { Secondary } \\
\text { school or } \\
\text { below }\end{array}$ & 6.7 \\
\hline & Diploma & 6.7 \\
\hline & Bachelor & 80 \\
\hline & $\begin{array}{c}\text { Master or } \\
\text { higher }\end{array}$ & 6.7 \\
\hline \multirow[t]{4}{*}{ Experience } & $\begin{array}{l}5 \text { yeas or } \\
\text { below }\end{array}$ & 23.3 \\
\hline & $6-10$ years & 36.7 \\
\hline & $11-15$ years & 16.7 \\
\hline & $\begin{array}{c}16 \text { years or } \\
\text { higher }\end{array}$ & 23.3 \\
\hline
\end{tabular}

\& accounting, legal, and marketing, respectively) meaning that all variables are important from the sample point view based on the questions developed. Further, Skweness and Kurtosis for normality tests confirming that all variables are normality distributed. Moreover, homogeneity assumptions were checked by analyzing the scatterplots of the regression standardized predicted values against the residuals (See Appendix 1/A for Q-Q plot of residuals).

Table (4) provides the correlation matrix of the variables used in the multivariate analysis. As it can be seen, the correlation coefficients reported indicated that there is a positive correlation between all explanatory variables and the use of Financial Leasing as a dependant variable.

\begin{tabular}{|l|c|c|c|c|}
\hline & Financial Leasing & $\begin{array}{c}\text { Tax \& } \\
\text { Accounting }\end{array}$ & Legal & Marketing \\
\hline Mean & 3.38 & 3.70 & 3.56 & 3.64 \\
\hline Median & 3.43 & 3.73 & 3.60 & 3.71 \\
\hline Standard Deviation & 0.78 & 0.49 & 0.54 & 0.81 \\
\hline Skewness & -0.03 & 0.34 & -0.17 & 0.57 \\
\hline Kurtosis & -1.20 & -0.22 & -0.68 & 0.15 \\
\hline Minimum & 2.14 & 2.82 & 2.57 & 1.50 \\
\hline Maximum & 4.71 & 4.82 & 4.71 & 5.00 \\
\hline
\end{tabular}

the sample has bachelor degree representing $80 \%$. Most of the sample had six to ten years of experience representing almost 37 , where those had 11 to 15 years of experience representing the lowest proportion of the sample $(16.7 \%)$. In addition, the mean of the questionnaire answers for all variables almost "agree" on the answers scale (i.e. the average of the answers are $3.4,3.7,3.6$, and 3.6 representing financial leasing, tax
Table-4: Correlation Matrix

\begin{tabular}{|l|l|l|l|}
\hline & LEAS & TAC & LEG \\
\hline TAC & $0.52^{* *}$ & & \\
\hline LEG & $0.39^{* *}$ & $0.39^{* *}$ & \\
\hline MAR & $0.42^{* *}$ & $0.45^{* *}$ & $0.55^{* *}$ \\
\hline
\end{tabular}

${ }^{*} \rho<.05 ;{ }^{* *} \rho<0.01$ 
The correlation coefficient was positively significant with all independent variables at 0.01 level of confidence. Empirical studies presented earlier in the literature section support our result in the relation between leasing and tax (Barclay and Smith 1995; Lasfer and Levis 1998; Ross and Stephen 2001). The positive correlation between leasing and the other two variables, legal and marketing, was also supported by the theoretical argument presented earlier in the literature section (Gao 1995; Gao and Hebbert 1996; McAdam 1988; Ross and Stephen 2001). Further, since the correlation between any two of the independent variables not exceeding 0.77 , it can be confirmed that multicollinearity among independent variable do not exist (Judge et al. 1985; Street and Bryant 2000; Wallace et al. 1994). Such a result confirmed by employing the stepwise regression technique showing that as variables were removed from the model, the coefficients of these variables, their standard errors, and the mean-square error remained relatively stable (See Appendix 1/B). Finally, correlation between the errors terms arising in time-series data, which called autocorrelation or serial correlation. Since the value of Durbin-Watson was around two, it means that autoccorelation problem did not exist (Maddala 2001) and consequently $R^{2}, t$-statistics, and $F$ are not exaggerated as presented in Table (5).

Table (5) reports the results on examining the impact of tax \& accounting, legal, and marketing on Financial Leasing used by Jordanian industrial companies listed on ASE using the multivariate analysis (i.e. OLS model).

Table (5) shows that $F$ value was significant. Therefore, overall, the explanatory variables do quite well at explaining the variations in the financial leasing. The adjusted $R^{2}$ is .304 . The tax \& accounting, legal, and marketing all have a statistically significant positive impact upon the financial leasing (See also Stepwise Regression results reported in Appendix 1/B). The value of $R^{2}$ and adjusted $R^{2}$ are almost similar, another multicollinearity checks confirming the correlation matrix test that the problem does not exist. Therefore, it could be argued that

Table-5: Tax \& Accounting, Legal, and Marketing Influence on Financial leasing

\begin{tabular}{|c|c|c|c|c|}
\hline & Constant & $\mathbf{T A C}$ & LEG & $\mathbf{M A R}$ \\
\hline a & -0.202 & 0.607 & 0.202 & 0.170 \\
\hline t-statistics & -0.361 & $4.021 * * *$ & $2.021 * *$ & $2.561 * *$ \\
\hline \multicolumn{5}{|c|}{ Dependent Variable: Financial leasing } \\
\hline F Value & & $15.57 *$ & & \\
\hline $\mathbf{R}^{2}$ & & 0.325 & & \\
\hline Adjusted $\mathbf{R}^{2}$ & & 0.304 & & \\
\hline Durbin-Watson & & 2.123 & & \\
\hline
\end{tabular}


which restricts competition and limits the entry on new players. Seventh, increase knowledge about leasing among companies stakeholders. Eighth, major constraint to expanding leasing in Jordan is the lack of long-term financing for leasing. Whereas banks can rely on term deposits, which are relatively cheap sources of funds, leasing companies must rely on equity or longerterm loans to fund their leasing portfolios, both of which are relatively more costly than bank deposits. In the absence of longerterm options, many leasing companies are forced to rely on short-term loans and lines of credit, which create a serious danger of mismatched maturities. Therefore, new regulations towards improving the leasing markets understanding opportunities are urgently required. Ninth, fixed rate and local-currency funding is also scarce which creates similar interest rate and currency risks. If a leasing company, therefore, does not have sufficient access to fixed rate loans, it will restrict its leasing portfolio, offer only variable rate leases or risk having their cost of funds (i.e. being mainly variable rate loans) rising above the rate they can earn on their leasing portfolios. None of these are conductive to the long-term health or stability of the leasing sector. As most leases are written in local currencies, it is equally important that sufficient local-currency funding is available to avoid having assets expressed in one currency and liabilities in another, thus creating foreign exchange risks that leasing companies should avoid whenever possible. Therefore, Longterm, fixed-rate funding in local currency is essential to the long-term health of the leasing industry in Jordan. While scarce today, more appropriate funding sources will likely be made available once the enabling environment for leasing in Jordan improves. This will require strengthening the legislative environment, removing imbalances in tax treatment, and improving the market's knowledge of leasing and its potential.

Future extensions would appear to be an appropriate step toward further understanding of the leasing market in Jordan by investigating: First, the financial drivers and implications of financial leasing among Jordanian economy sectors. Second, evaluating lessees companies specific factors (i.e. performance, liquidity, risks, market measures, and ownership structure). Third, the differences among various types of leasing contracts. Fourth, the oligopolistic leasing markets structure and its existence in Jordan. Fifth, financial leasing contracts valuation under high inflation rates.

\section{CONCLUSION}

Leasing is increasingly developing both as a financial instrument and a growing industry in Jordan following the country's transition to a capital market economy joining the global efforts in privatization and cross-boarders investments flow. The late 1990 s have witnessed the beginnings of legalizing the leasing market in the country and the evolution of new regulations reforms concerning companies act, tax law, ASE regulations, accounting standards considered (i.e. Jordan has started adopting the International Financial Reporting Standards (IFRS) since 1998) and other legislations. To provide further insight of financial leasing in Jordan, this paper investigated the leasing market development in general in terms of legislations and market features. In addition, the study examined the influence of $\operatorname{tax} \&$ accounting, 


\section{REFERENCES}

Abu-Haswa, Ziad (2005), "Finance Lease Contract: A Comparative Study." Amman: World Bank Group.

Adedeji, A.; and R. C. Stapleton (1996), "Leases, Debt and Taxable Capacity," Applied Financial Economics, 6, PP. 71-83.

Al Rai, Daily Magazine (2007), "Financial Leasing: History and Present," in Alrai Daily Magazine Vol. No. 13354.

Anderson, P. F. (1980), "Leasing: An Industrial Marketing Tool," in Unpublished manuscript provided by the American Association of Equipment Lessors.

Arab Bank (2006): www.arabbank.com.

ASE (2008), "Jordanian Shareholding Companies Guide." Amman - Jordan: Amman Stock Exchange.

Barclay, M. J.; and C. W. Smith (1995), "The Priority Structure of Corporate Liabilities," Journal of Finance, 50, PP. 889-917.

Bathala, C. T.; and T. K. Mukherjee (1995), "A Survey of Leasing in Small Firms," Journal of Small Business Finance, 4, PP. 113-27.

Beattie, V.; A.; Goodacre, and S. Thomas (2000), "Operating Leases and the Assessment of Lease-Debt Substitutability," Journal of Banking \& Finance, 24, PP. 427-70.

Brick, I. E.;, W.; Fung, and M. Subrahmanyam (1987), "Leasing and Financial Intermediation: Comparative Tax Advantages," Financial Management, PP. 55-59.

Brigham, E. F.; and L. C. Gapenski (1985), Financial Management (4th ed.). New York, N.Y.: The Dryden Press.

CBI, Central Bank of Jordan (2005), "Annual Report." Amman: Central Bank of Jordan.

-.-- (2007), “Annual Report." Amman: Central Bank of Jordan.

DOS (2007), "Department of Statistics Yearly Statistical Series." Jordan - Amman:

Department of Statistics (DOS).

Eades, K. M.; and F. C. Marston (2002), "Incentives for Leasing: Evidence from the Largest US Lessees and Lessors," Working Paper, University of Virginia.

Euromoney (2006), "World Leasing Yearbook."

Finucane, T. J. (1988), "Some Empirical Evidence on the Use of Financial Leases," Journal of Financial Research, PP. 321-33.

Gao, Simon S. (1995), "Leasing in Poland- Privatization, Financing, and Current Problems," European Business Review, 5, PP. 31 - 39.

Gao, Simon S.; and E. Wilson Hebbert (1996), "Lease Finance in Emerging Markets: An Eastern European Study," Managerial Finance, 22 (12), PP. 39-49.

Graham, J. R. (2003), "Taxes and Corporate Finance: A Review," Review of Financial Studies, 16, PP. 1075-129.

Graham, J. R.; L. L.; Michael, and S. S. James (1998), "Debt, Leases, Taxes, and the Endogeneity of Corporate Tax Status," Journal of Finance, 53, PP. 131-62. 
IFC, International Finance Corporation (2006), "A Study of the Leasing Market in the Hashimate Kingdom of Jordan." Amman: World Bank Group.

Jordan Investment Board (2007): www.jordaninvestment.com.

Jordanian Islamic Bank (2007): www.jordanislamicbank.com.

Judge, G., W. Griffiths, R. Hill, H. Lutkepohl, and T. Lee (1985), The Theory and Practice of Econometrics (2nd ed.). U.S.A - New York: John Wiley \& Sons.

Kieso, D. E.; and J. J. Weygandt (1998), Intermediate Accounting (9th ed.). New York, N. Y.: John Wiley \& Sons, Inc.

Kinnear, P. R. and C. D. Gray (1995), SPSS for Windows Made Simple. Erlbasm - UK: Taylor and Francis Publishers.

Krahan, J. P.; and G. Meran (1987), Why leasing? An Introduction to Comparative Contractual Analysis. Berlin: Bamberg, G. \& Spremann, K., eds.

Kraljic, A. P. (1990), "The Economic Gap Separating East and West," Columbia Journal of World Business, PP. 14-19.

Krishnan, V. S.; and R. C. Moyer (1994), "Bankruptcy Costs and the Financial Leasing Decision," Financial Management, Vol. 23 (No. 2), PP. 31-42.

Lasfer, M. A.; and M. Levis (1998), "The Determinants of the Leasing Decision of Small and Large Companies," European Financial Management, 4, PP. 159-84.

Lasfer, Meziane (2007), "On the Financial Drivers and Implications of Leasing Real Estate Assets: The Donaldsons-Lasfer's Curve," Journal of Corporate Real Estate, 9 (2), PP. 72-94.

Lease, R. C.;, J. J.; McConnell, and J. S. Schallheim (1990), "Realized Returns and the Default Prepayment Experience of Financial Leasing Contracts," Financial Management, PP. 11-20.

Lewis, C. M.; and J. S. Schallheim (1992), “Are Debt and Leases Substitutes?," Journal of Financial and Quantitative Analysis, PP. 497-511.

LFG, London Financial Group (1996), "Euromoney Publication: World Leasing Yearbook." U.K., London: London Financial Group.

Lowe, J. F.; , Morgan;, and Tomkins C. R. (1980), "Lease Finance in Industrial Markets," Management and Decision Economics, 1 (3), PP. 150-56.

Maddala, G. S. (2001), Introduction to Econometrics (3rd ed.). UK - Sussex: John Wiley \& Sons Ltd.

Malone, D., C. Fries, and T. Jones (1993), "An Empirical Investigation of the Extent of Disclosure in the Oil and Gas Industry," Journal of Accounting, Auditing and Finance, Vol. 8 (No. 3), PP. 249-73.

Marston, F.; and R. S. Harris (1988), "Substitutability of Leases and Debt in Corporate Capital Structure," Journal of Accounting, Auditing \& Finance, PP. 147-69.

McAdam, M. Bruce (1988), "Equipment Leasing: An Integral Part of Financial Services," Business Economics, 23 (3), PP. 43-47.

Merhan, Hamed;, R. A.; Taggart, and D. Yermack (1999), "CEO Ownership, Leasing, and Debt Financing," Financial Management, 28, PP. 5-14.

Ministry of Industry and Trade (2007): www.mit.gov.jo. 
Ministry of Planning (2007): www.mop.gov.jo.

Mukherjee, T. K. (1991), "A Survey of Corporate Leasing Analysis," Financial Management, 20, PP. 96-107.

Myers, S. C. (1977), "Determination of Corporate Borrowing," Journal of Financial Economics, 5, PP. 147-75.

Norusis, M. J. (1995), SPSS 6.1 Guide to Data Analysis: Prentice-Hall Englewood Cliffs, NJ.

Ross, L.; and C. Stephen (2001), "The Leasing Industry's Legal Environment Improves," The China Business Review, January-February, PP. 48-51.

Schallheim, J. S.;, R. E.; Johnson, R.C.; Lease, and McConnell (1987), "The Determinants of Yields on Financial Leasing Contracts," Journal of Financial Economics, PP. 45-67.

Sharpe, S. A.; and H. H. Nguyen (1995), "Capital Market Imperfection and the Incentive to Lease," Journal of Financial Economics, 39 (PP. 271-94).

Smith, C. W.; and L. M. Wakeman (1985), "Determinants of Corporate Leasing Policy," Journal of Finance, PP. 895-908.

Street, D. L. and S. M. Bryant (2000), "Disclosure Level and Compliance with IASs: A Comparison of Companies with and without U.S. Listing and Filings,", The International Journal of Accounting, Vol. 35 (No. 3).

Stulz, R. M.; and H. Johnson (1985), “An Analysis of Secured Debt,” Journal of Financial Economics, PP. 501-21.

Thomas, R. L. (1997), Modern Econometrics: An Introduction (2nd ed.). England - Essex: Wesley Longman Limited.

Vora, P. P.; and J. R. Ezzell (1991), "Leasing vs. Purchasing: Direct Evidence on a Corporation's Motivations for Leasing and Consequences of Leasing," Pennsylvania State University Working Paper.

Wallace, R. S. O. and K. Naser(1995), "Firm-Specific Determinants of the Comprehensiveness of Mandatory Disclosure in the Corporate Annual Reports of Firms Listed on the Stock Exchange of Hong Kong," Journal of Accounting and Public Policy, Vol. 14, PP. 311-68.

Wallace, R. S. O., K. Naser, and A. Mora (1994), "The Relationship between the Comprehensiveness of Corporate Annual Reports and Firm Characteristics in Spain," Accounting and Business Research, Vol. 25 (No. 97), PP. 41-53.

Williamson, O. E. (1988), "Corporate Finance and Corporate Governance," Journal of Finance, 43, PP. 41-47.

\section{Short Bio of Mohammad Salam Al-Shiab and Shamsi Bawnih}

Mohammad Salam Al-Shia is an Assistant Professor, Department of Finance, King Saud University, Saudi Arabia. He received his PhD from Newcastle University, U.k.

Shamsi Bawnih is working in the MIS Department, Princess Sumaya University College for Technology, Jordan 


\section{Appendix 1}

\section{A- Normality Test}

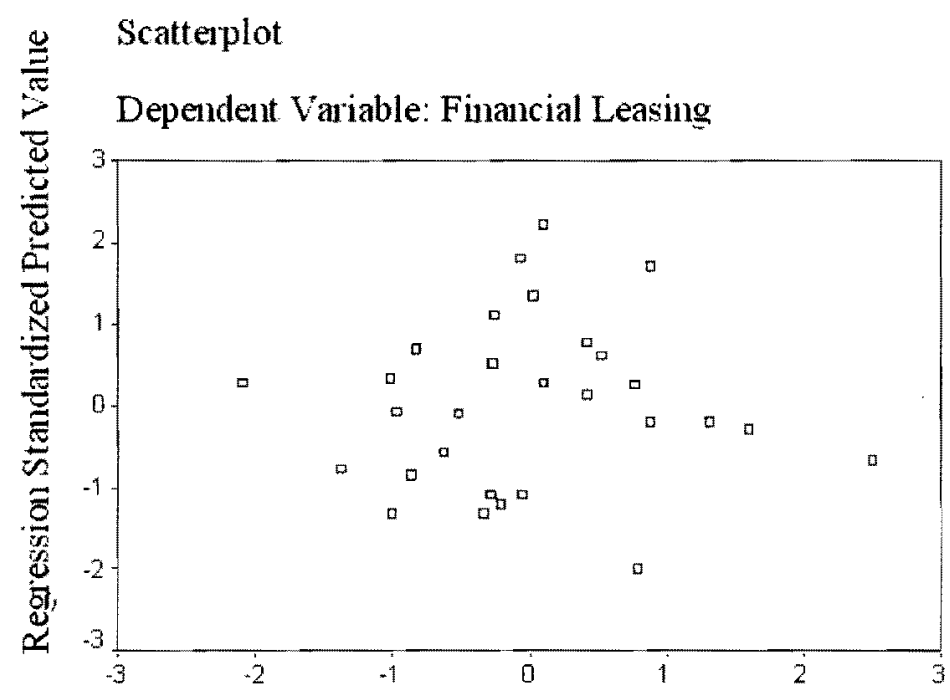

\section{Regression Standardized Residual}

\begin{tabular}{|c|c|c|c|}
\hline \multicolumn{3}{|c|}{ Variables Entered/Removed } \\
\hline Model & Variables Entered & $\begin{array}{c}\text { Variables } \\
\text { Removed } \\
\text { Legal }\end{array}$ & $\begin{array}{c}\text { Method } \\
\text { Stepwise (Criteria: Probability-of- } \\
\text { F-to-enter }<=.050, \text { Probability-of- } \\
\text { F-to-remove }>=.100) .\end{array}$ \\
\hline 2 & $\begin{array}{c}\text { Tax \& Accounting } \\
\text { Marketing }\end{array}$ & Larketing & $\begin{array}{l}\text { Stepwise (Criteria: Probability-of- } \\
\text { F-to-enter }<=.050, \text { Probability-of- } \\
\text { F-to-remove }>=.100) .\end{array}$ \\
\hline 3 & $\begin{array}{c}\text { Tax \& Accounting } \\
\text { Marketing } \\
\text { Legal }\end{array}$ & - & $\begin{array}{c}\text { Stepwise (Criteria: Probability-of- } \\
\text { F-to-enter }<=.050, \text { Probability-of- } \\
\text { F-to-remove }>=.100) .\end{array}$ \\
\hline
\end{tabular}


B- Stepwise Regression Test

\begin{tabular}{|c|c|c|c|c|c|c|}
\hline \multicolumn{7}{|c|}{ ANOVA } \\
\hline Model & & Sum of Squares & df & Mean Square & $\mathrm{F}$ & Sig. \\
\hline \multirow[t]{3}{*}{1} & Regression & 16.23 & 1 & 16.23 & 36 & 0.000 \\
\hline & Residual & 44.77 & 99 & 0.45 & & \\
\hline & Total & 60.99 & 100 & & & \\
\hline \multirow[t]{3}{*}{2} & Regression & 19.03 & 2 & 9.52 & 22 & 0.000 \\
\hline & Residual & 41.96 & 98 & 0.43 & & \\
\hline & Total & 60.99 & 100 & & & \\
\hline \multirow[t]{3}{*}{3} & Regression & 22.01 & 3 & 7.34 & 18.35 & 0.000 \\
\hline & Residual & 39.15 & 97 & 0.40 & & \\
\hline & Total & 60.99 & 100 & & & \\
\hline $\mathrm{a}$ & \multicolumn{6}{|c|}{ Predictors: (Constant), Tax \& Accounting } \\
\hline b & \multicolumn{6}{|c|}{ Predictors: (Constant), Tax \& Accounting, Marketing } \\
\hline c & \multicolumn{6}{|c|}{ Predictors: (Constant), Tax \& Accounting, Marketing, Legal } \\
\hline $\mathrm{d}$ & Dependent Va & e: Financial Leasir & & & & \\
\hline
\end{tabular}

\begin{tabular}{|c|c|c|c|c|l|}
\hline Model Summary \\
\hline Model & $\boldsymbol{R}$ & R Square & $\begin{array}{c}\text { Adjusted R } \\
\text { Square }\end{array}$ & $\begin{array}{c}\text { Std. Error of the } \\
\text { Estimate }\end{array}$ & Durbin-Watson \\
\hline 1 & 0.52 & 0.27 & 0.26 & 0.67 & \\
\hline 2 & 0.56 & 0.30 & 0.30 & 0.65 & \\
\hline 3 & 0.59 & 0.32 & 0.32 & 0.64 & 2.045 \\
\hline a & Predictors: (Constant), Tax \& Accounting & \\
\hline b & Predictors: (Constant), Tax \& Accounting, Marketing \\
\hline c & \multicolumn{5}{l}{ Predictors: (Constant), Tax \& Accounting, Marketing, Legal } \\
\hline d & Dependent Variable: Financial Leasing \\
\hline
\end{tabular}

\section{C- Reliability Test}

\begin{tabular}{|l|}
\hline Reliability Coefficients \\
\hline $\mathrm{N}$ of Cases $=101$ \\
\hline Alpha $=.7479$
\end{tabular}

